\title{
Functional insights into the role of seminal plasma proteins on sperm motility of buffalo
}

\author{
Viviane Maria Codognoto*,1, Paulo Henrique Yamada $^{1}$, Rúbia Alves Schmith ${ }^{1}$, \\ Felipe Rydygier de Ruediger ${ }^{1}$, Caroline Scott ${ }^{1}$, Patrícia de Faria Lainetti ${ }^{1}$, \\ Suzane Brochine $^{1}$, Camila de Paula Freitas-Dell'Aqua ${ }^{1}$, Fabiana Ferreira de Souza ${ }^{1}$, \\ Eunice $\mathrm{Oba}^{1}$
}

São Paulo State University (UNESP), School of Veterinary Medicine and Animal Science, Department of Animal Reproduction and Veterinary Radiology, Botucatu, Brazil

\section{A R T I C L E I N F O}

\section{Keywords:}

Biomarker

Male

Proteomic

Sperm

\begin{abstract}
A B S T R A C T
The objective of the present study was to describe the proteins from the seminal plasma of buffalo and correlate these proteins with sperm motility. Ejaculates from sixteen Murrah buffalo were used. Semen collection was performed by electroejaculation, and the ejaculate was evaluated by macroscopic (volume) and microscopic analysis (subjective motility and vigor, as well as sperm concentration). After the analysis, the samples were centrifuged ( $800 \mathrm{~g}$ for $10 \mathrm{~min}$ and 10,000 for $30 \mathrm{~min}$ at $4{ }^{\circ} \mathrm{C}$ ), and the supernatant (seminal plasma) was used to determine total protein concentration by the Bradford method. Based on total protein concentration, an aliquot $(50 \mu \mathrm{g})$ was taken to conduct protein in-solution digestion for nano-LC-ESI-Q-TOF mass spectrometry analysis. Samples were divided into two groups, minimal (little sperm motility) and greater (typical sperm motility), based on non-hierarchical clustering considering motility and emPAI protein value. The data were analyzed by multivariate statistical analysis using principal component analysis (PCA) and partial analysis of minimum squares discrimination (PLS-DA). Fortyeight proteins were detected in the seminal plasma, and fifteen were common to two groups. There were six proteins that were significantly different between the groups. The main functions of proteins in seminal plasma were catalytic and binding activity. Spermadhesin protein, ribonuclease, 14-3-3 protein zeta/delta and acrosin inhibitor were in greater amounts in seminal plasma from the group with greater sperm motility; prosaposin and peptide YY were in greater amounts in the group with little sperm motility. The proteins detected in the greater motility group were correlated with sperm protection, including protection against oxidative stress, lipid peroxidation, protease inhibition and prevention of premature capacitation and acrosome reaction. In the group with little sperm motility, one of the identified proteins is considered to be an antifertility factor, whereas the function of other identified protein is not definitive. Results from the present study add to the knowledge base about the molecular processes related with sperm motility, and these findings can be used for determining potential markers of semen quality.
\end{abstract}

\footnotetext{
* Corresponding author at: Department of Animal Reproduction and Veterinary Radiology, Faculty of Veterinary Medicine, FMVZ, São Paulo State University (UNESP), Botucatu, São Paulo, Brazil.

E-mail address: viviane.codognoto@gmail.com (V.M. Codognoto).

${ }^{1}$ These authors have contributed equally to this research.
} 


\section{Introduction}

Seminal plasma is a fluid composed of a complex mixture, which contains different macromolecules from the testes, epididymis and accessory sexual glands with the function of maintaining viability of sperm cells. Proteins are the main macromolecules contained in seminal plasma, which have been correlated with male fertility in different species (Alvarez and Storey, 1995; Calvete et al., 1997; Daskalova et al., 2014; Kumar and Swamy, 2016), including cattle (Killian et al., 1993; Manjunath and Thérien, 2002). The functions of these proteins were related to sperm motility (Govindaraju et al., 2012), maintenance of a sperm reservoir in the female reproductive duct system (Singleton and Killian, 1983), capacitation (Killian et al., 1993; Manjunath and Thérien, 2002; Souza et al., 2011), acrosome reaction (Killian et al., 1993; Riffo and Párraga, 1997; Kummar et al., 2012), gamete fusion (Souza et al., 2008; Monaco et al., 2009), cell protection (Alvarez and Storey, 1995; Moura et al., 2007; Roncoletta et al., 2006) and fertilization (Thérien et al., 1997; Erikson et al., 2007). Nevertheless, in buffalo, few studies have been conducted to assess seminal protein content (Huang et al., 2015).

There is increasing interest in heparin binding proteins (HBPs) in buffalo, because most studies have focused on a seminal plasma proteomic approach in evaluation of HBPs (Arangasamy et al., 2005; Harshan et al., 2006, 2009; Kumar et al., 2008; Singh et al., 2007, 2013, 2014). Moreover, there may be an influence of the seminal plasma composition on the capacity to freeze semen from buffalo, because this species has a poor fertility rate after artificial insemination with frozen/thawed semen (Anzar et al., 2003; Akhter et al., 2007; Andrabi, 2009).

Harshan et al. (2006) studied effects of HBPs addition to epididymal spermatozoa of buffalo and found a poor freezing capacity, when there were greater concentrations of these proteins as a result of semen supplementations with HBPs. A similar interaction mechanism was proposed to buffalo as occurs between HBPs from sperm cell with lipids of egg yolk during cryopreservation of bovine spermatozoa (Singh et al., 2007). Lipids of egg yolk, after dilution of semen to freeze, interact with the HBPs, particularly the BSP proteins, forming complexes that prevent the binding of HBPs to the sperm membrane and inhibit the action of proteins (Manjunath and Thérien, 2002). In bovine, although the BSPs are beneficial to sperm functions, are associated with cholesterol and phospholipid efflux (Thérien et al., 1998, 1999), which is detrimental to the sperm membrane during cryopreservation (Manjunath et al., 2002).

Other hypotheses have been put forth in attempts to explain the lesser fertility rate of buffalo after cryopreservation of semen as compared to what occurs in cattle. Buffalo have a lesser semen protein concentration, which is thought to result in a lesser sperm motility, viability and fertility (Kulkarni et al., 1998; Dixit et al., 2016). The addition of bull seminal plasma to epididymal spermatozoa from buffalo, however, had detrimental effects on these semen quality markers (Herold et al., 2004). These results were confirmed by Singh et al. (2014), where a specific protein was identified, PDC-109 (BSP1), which is an HBP that was isolated from bull seminal plasma that when added to semen from buffalo there was a lesser freezing capacity of the treated samples.

Even though there have been these previous studies on protein composition of seminal plasma and the freezeability of buffalo semen, the relationship of proteins with sperm motility has not been thoroughly elucidated. Sperm motility is modulated by proteins contained in seminal plasma (Govindaraju et al., 2012), although specific mechanisms of action remain unclear in buffalo (Huang et al., 2015). Thus, the objective of the present study was to describe the main proteins of seminal plasma of buffalo by using mass spectrometry and correlate these molecules with sperm motility.

\section{Materials and methods}

\subsection{Reagents}

All reagents used in the present study were of the greatest purity and obtained from Sigma-Aldrich (St. Louis, MO, USA), GE Healthcare Life Sciences (São Paulo, São Paulo, Brazil), Waters Corp. (Barueri, São Paulo, Brazil) and Thermo Fisher Scientific (São Paulo, São Paulo, Brazil), unless otherwise cited.

\subsection{Ethical aspects}

The study was performed in accordance with ethical recommendations of the National Council for the Control of Animal Experimentation (CONCEA), and with the approval of the Committee on Ethics in the Use of Animals protocol 95/2016.

\subsection{Animals, collection and semen evaluation}

The groups were composed for animals that allowed the collection by electroejaculation. Sixteen adult (2.5 to 5.0 years), Murrah, clinically healthy buffalo (Bubalus bubalis), a $>30 \mathrm{~cm}$ scrotal circumference of unknown fertility from a single farm were used. The animals were maintained in an extensive grazing condition (Brachiaria decumbens), receiving water and mineral salt ad libitum.

After collection, the semen was analyzed according to the macroscopic (volume) and microscopic (subjective analyses of sperm motility and vigor, and concentration) characteristics.

Volume was measured with a graduated tube. Motility and vigor were subjectively analyzed by placing a semen drop on a glass slide, overlaid by a coverslip, and observing by optical microscopy (Bioval, L1000b-AC, Hexasystems Group, Taboão da Serra, Brazil), at $100 \times$ magnification. Sperm motility was classified as a percentage ( $0 \%$ to $100 \%)$, where $100 \%$ indicates all cells with movement, and $0 \%$ indicates no cells with movement. Sperm vigor was evaluated by using a score from 0 to 5 , where 0 represented no 
movement, and 5 rapid and vigorous movements. A semen aliquot was diluted (1: 200) in formol-saline to determine sperm concentration using a Neubauer chamber. The cells were countered in an optical microscopy at $400 \times$ magnification.

\subsection{Proteomics}

After the semen evaluation, the samples were centrifuged at $800 \mathrm{~g}$ for $10 \mathrm{~min}$ for seminal plasma recovery. The supernatant (seminal plasma) was added to a buffer containing protease inhibitors $(0.8 \mathrm{mM}$ EDTA, $1 \mu \mathrm{g} / \mathrm{mL}$ aprotinin, $1 \mu \mathrm{g} / \mathrm{mL}$ leupeptin and $35 \mu \mathrm{g} / \mathrm{mL}$ PMSF in $50 \mathrm{mM}$ Tris-HCl, $\mathrm{pH}$ 7.2) and immediately frozen. In the laboratory, the seminal plasma samples were thawed in an ice bath and re-centrifuged at $10,000 \mathrm{~g}$ for $30 \mathrm{~min}$ at $4{ }^{\circ} \mathrm{C}$. The total protein concentration was measured by the Bradford method (Sigma-Aldrich, São Paulo, Brazil) by using a spectrophotometer (Ultrospec 2000, Pharmacia Biotech, Ultrospec 2000 UV/VIS Spectrophotometer, Uppsala, Sweden) based on a standard curve made from known concentrations of bovine serum albumin.

Seminal plasma proteins were digested in solution using the procedures previously reported by Villén and Gygi (2008) with several modifications. An aliquot containing $50 \mu \mathrm{g}$ of total protein was separated and added to an aqueous solution of $8 \mathrm{M}$ urea (1: 2) followed by reduction of the disulfide bridges with $5 \mathrm{mM}$ DTT in $50 \mathrm{mM}$ ammonium (aqueous solution) for $25 \mathrm{~min}$ at $56^{\circ} \mathrm{C}$. The samples were alkylated with $14 \mathrm{mM}$ iodoacetamide in $50 \mathrm{mM}$ ammonium bicarbonate in the final solution for $30 \mathrm{~min}$ at room temperature, protected from light. Excess free iodoacetamide (quench) was performed by adding $5 \mathrm{mM}$ DTT in $50 \mathrm{mM}$ ammonium bicarbonate in the final solution for $15 \mathrm{~min}$, protected from light, at room temperature. Samples were diluted in $50 \mathrm{mM}$ ammonium bicarbonate (1: 5) to reduce the urea concentration to $<1.6 \mathrm{M}$ and added with $1 \mathrm{mM}$ aqueous $\mathrm{CaCl}_{2}$ solution in the final solution. A solution of $20 \mathrm{ng} / \mu \mathrm{L}$ trypsin (ratio of 1: 50 enzyme: substrate) was subsequently added to the sample followed by incubation at $37{ }^{\circ} \mathrm{C}$ for $16 \mathrm{~h}$. The enzymatic action of trypsin was stopped with aqueous solution $0.4 \%$ trifluoroacetic acid (TFA), and the pH was assessed $(<2.0)$. The samples were then centrifuged at room temperature for $10 \mathrm{~min}$ at $2500 \mathrm{~g}$.

The collected supernatant was subjected to desalting of the peptides in reverse phase columns (SepPack C18 WAT054955, Waters Corporation, Milford, MA, USA), according to the manufacturer's instructions. After desalting, the volume was reduced ( $\sim 1 \mu \mathrm{L})$ in a vacuum concentrator (SPD1010 Integrated SpeedVac ${ }^{\mathrm{TM}}$ Systems, Thermo Fisher Scientific Inc., Waltham, MA, USA) and the samples stored at $-20^{\circ} \mathrm{C}$ until analysis by mass spectrophotometry.

For mass spectrometry, the samples were thawed, diluted in formic acid $0.1 \%$ in the proportion of $0.7 \mu \mathrm{g} / \mu \mathrm{L}$, homogenized in shaker and centrifuged at $1100 \mathrm{~g}$ for $5 \mathrm{~min}$. The supernatant was removed $(20 \mu \mathrm{L})$, and deposited in glass tubes (Clear glass $12 \times 32 \mathrm{~mm}$ screw neck total recovery vial, Waters Corporation, Milford, MA, USA).

Protein analysis was performed according to Aragão et al. (2012). An aliquot of $4.5 \mu \mathrm{L}$ resulting from peptide digestion was separated by column C18 $(100 \mu \mathrm{m} \times 100 \mathrm{~mm})$ RP nano UPLC (NanoAcquity, Waters Corporation, Milford, MA, USA) coupled to the Q-TofPremier mass spectrometer (Waters Corporation, Milford, MA, USA) with nanoelectrospray at a flow rate of $0.600 \mu \mathrm{L} / \mathrm{min}$.

The gradient was with $2 \%$ to $90 \%$ acetonitrile with $0.1 \%$ formic acid for $45 \mathrm{~min}$. The voltage of the nanoelectroctrospray was $3.5 \mathrm{kV}$, the voltage cone of $30 \mathrm{~V}$ at $100 \mu \mathrm{C}$. The apparatus was operated in the top three mode in which an MS spectrum was acquired followed by MS/MS of the three most intense peaks detected. After MS/MS fragmentation, the ion was placed on the exclusion list for $60 \mathrm{~s}$. Endogenous cleavage peptides were analyzed by using real-time deletion. The spectra were acquired by using MassLynx v.4.1 software, and the raw data files were converted to a peak list format (.mgf) without adding the scans from the Mascot Distiller software v.2.3.2.0, 2009 (Matrix Science Ltd., Boston, MA, USA) with carbamidomethylation with fixed modifications, oxidation in methionine with variable modification, a trypsin cleavage, and tolerance of $0.1 \mathrm{Da}$ for the precursor ions of fragment. The relative quantification of each protein in the mixture was determined by the exponentially modified protein abundance index (empaI) (Ishihama et al., 2005), obtained by Mascot Distiller software (Matrix Science Inc., Boston, MA USA).

\subsection{Gene ontology}

The gene ontology of each protein was obtained from UniprotKB (www.uniprot.org, Boutet et al., 2016) by the molecular function, biological process and cellular component categories using the Mammalia taxonomy. Figures on gene ontology were obtained online at http://www.pantherdb.org, Panther version 10 (Mi et al., 2016).

\subsection{Data analysis}

Normalization of the data was performed to exclude proteins that did not appear in at least half of the evaluated group; thus, the differences between the samples were adjusted, and the variables were made more reliable for an accurate analysis. In addition, the sum of the emPAI of each protein from each animal was divided by the total protein count to determine the division used for the statistical analysis.

The non-hierarchical clustering was used to divide the groups considering motility and emPAI protein value. Initially, the groups were randomly divided with user-supplied data. Software was subsequently used to calculate the mean of the cluster and replicates were performed until none of the observations were reassigned to a different cluster. Multivariate statistical analysis of proteomic data was performed in the online free software MetaboAnalyst 3 (Xia and Wishart, 2016), in which principal component analysis (PCA) was used to describe the variation of the sample (animals) in the matrix of punctuation and partial analysis of minimum squares discrimination (PLS-DA) to indicate the relevance of proteins in characterizing each group. The PSL-DA was used to assign samples according to classes, indicating a ranking and calculating the variables' importance on projection score (VIP score). The important proteins were considered as VIP score was $\alpha \geq 1$ (Checa et al., 2015). Protein abundance (emPAI) in the bad and good 


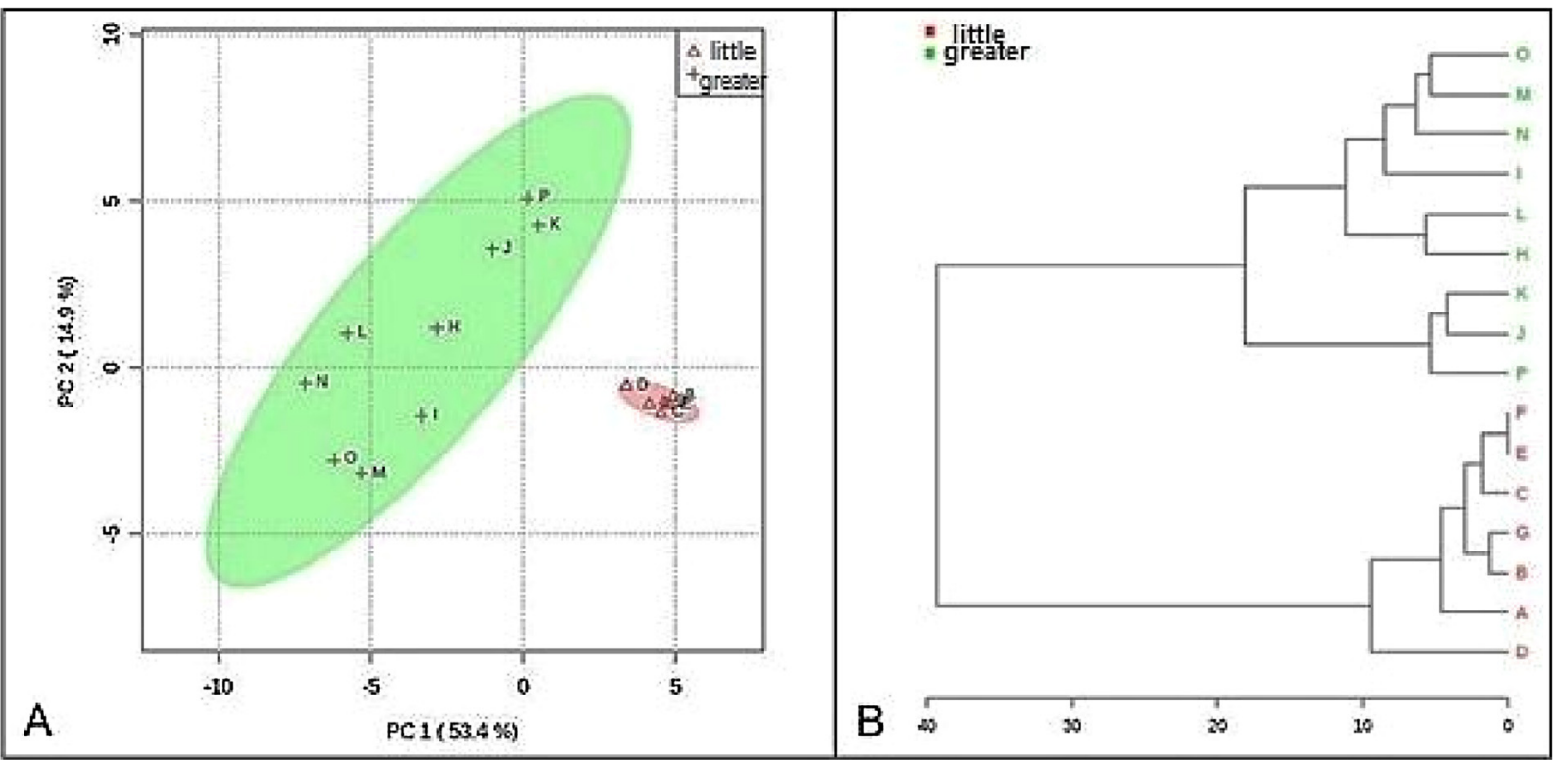

Fig. 1. Principal component analysis (PCA) score. PC1 and PC2 for seminal plasma of males classified into groups with little and greater sperm motility, indicating the variations between groups $(\mathrm{PC} 1+\mathrm{PC} 2=68.3 \%)$. A. Note the distance measure of clusters (green and pink). B. Clustering results shown as dendogram (For interpretation of the references to colour in this figure legend, the reader is referred to the web version of this article).

groups was performed by using a t-test.

\section{Results}

According to sperm motility (mean \pm standard error; $56.25 \pm 4.44)$, the animals were divided in two groups [greater $(n=9)$ and little $(\mathrm{n}=7)$ sperm motility] by using PCA, and the results are provided in a dendogram (Fig. 1). The mean motility in each group was $37.9 \%$ for the group with little and $70.6 \%$ for the group with greater sperm motility. The sum principal components (axis $\mathrm{X}$ and Y) 1 and 2 was $68.3 \%$, which confirmed the accuracy of the division between groups.

Using mass spectrometry, 48 proteins were identified in the seminal plasma of the groups with greater and little sperm motility. Information about the proteins identified in each group is included in Fig. 2. The identified proteins were described in Supplement 1 considering biological process, molecular function and cellular compartment.

Considering all the clusters, the gene ontology assessments identified catalytic activity (44\%) and binding (35\%) as the main molecular functions, and biological processes and there were also cellular (25\%) and metabolic process (21\%) identified. In relation to the cellular compartment, the proteins are mainly located in the cellular (50\%), extracellular (22\%) region, and the main classes of proteins were hydrolases (16\%) and cytoskeleton proteins (16\%).

In the analysis of PLS-DA, considering the groups with little and greater sperm motility and the relative abundance (emPAI) of the proteins identified, 11 proteins were determined as relevant (Fig. 3), of which four lesser abundance proteins were identified in the

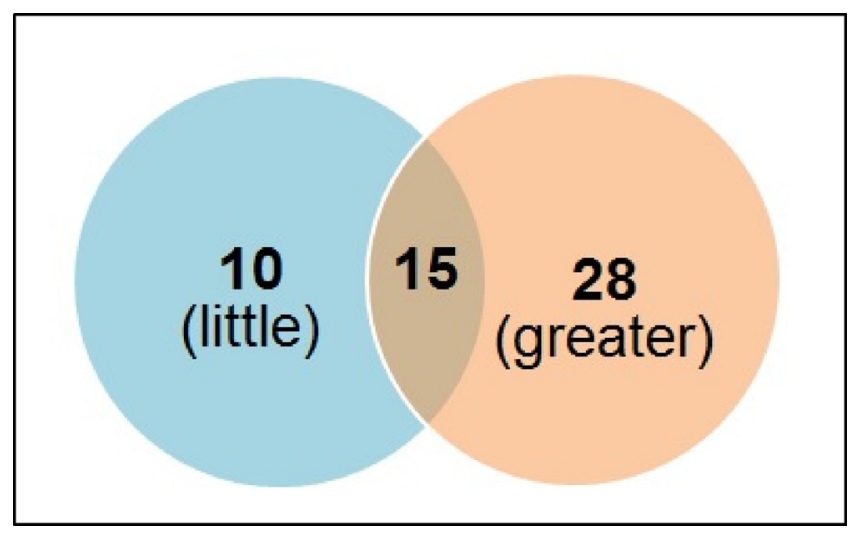

Fig. 2. Venn diagram of the proteins detected in seminal plasma of males with little or greater sperm motility. 


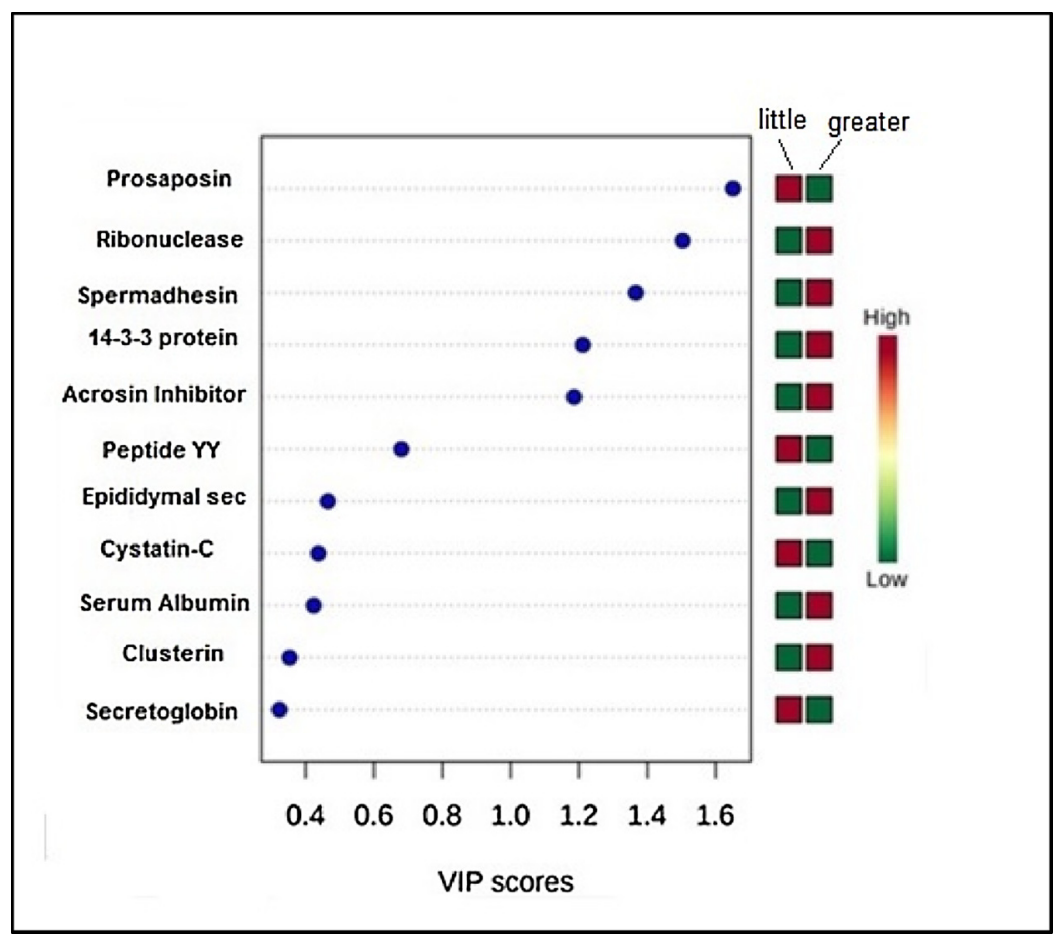

Fig. 3. VIP (variable importance projection) score classified by PLS-DA. The colored boxes on the right indicate the corresponding relative protein concentrations in seminal plasma of males with little or greater sperm motility.

group with little sperm motility, and seven proteins of greater abundance were identified in the group with greater sperm motility. Although the VIP score threshold has been fixed as $\geq 1(\alpha \geq 1)$, there was a range of 0.4 to 1.6. At least five ( $\alpha \geq 1)$ relevant proteins were identified (prosaposin, ribonuclease, spermadhesin, 14-3-3 protein zeta/delta and acrosin inhibitor).

\section{Discussion}

For the formation of the two clusters of males based on semen quality, the experimental variable sperm motility was analyzed in the present study. The classification of the clusters was confirmed with the PCA, which was relevant due to the sum ( $>50 \%$ ) of principal components 1 and 2 (Lyra et al., 2010). Similar results were also observed in the dendogram, which indicated there were animals in two populations based on sperm quality in the two groups.

The molecular functions associated with the proteins were 1) catalytic and binding activity and biological processes, and 2) cellular and metabolic processes in the cellular and extracellular region, consistent with the results of Rego et al. (2014), where seminal plasma protein of bulls was assessed.

In the present study, the spermadhesin protein, ribonuclease, 14-3-3 protein zeta/delta and acrosin inhibitor, were in greater amounts in seminal plasma of buffalo with greater quality sperm. Furthermore, prosaposin and peptide YY were detected in the seminal plasma of all animals with sperm that were classified to have little motility.

Spermadhesin, produced by the accessory sexual glands and epididymis (Einspanier et al., 1991; Wempe et al., 1992), was present in greater concentrations in the seminal plasma of males of the present study that were classified to have greater sperm motility, consistent with the earlier findings of Jobim et al. (2003, 2004) and Roncoletta et al. (2006) in which seminal plasma proteins of bulls was assessed. The spermadhesins are the second most abundant proteins secreted in the seminal plasma of bulls (Rego et al., 2014), which function in the inhibition of oxidative stress and reduction of lipid peroxidation of sperm cells (Jobim et al., 2003). The grater amounts of spermadhesin and, thus, presumably enhanced functions of these proteins may have contributed to the greater sperm motility in the males classified to have greater sperm motility in the present study. In addition, spermadhesin functions as a decapacitating factor in sperm cells stored in the ampulla before ejaculation, preventing sperm motility and energy consumption (Einspanier et al., 1991; Wempe et al., 1992; Dostàlovà et al., 1994; Roncoletta et al., 2006; Kummar et al., 2012). The reestablishment of sperm motility occurs when the spermatozoa come in contact with the secretions of the female reproductive tract, and the effect of spermadhesin motility inhibition of sperm cells is reversed (Dostàlovà et al., 1994; Schöneck et al., 1996).

The ribonuclease, isolated from the seminal vesicle and ampulla (D'Alessio et al., 1972; Matousek and Klaudy, 1998; Rego et al., 2014), was reported in seminal plasma of bulls as being involved in spermatogenesis and sperm capacitation (D'Alessio et al., 1972; Kim et al., 1995). This enzyme has an antioxidant function and catalytic activity in addition to functioning in immunosuppression, protecting the sperm from actions of the immune system in the female reproductive tract (Quayle and James, 1990; D'Alessio et al., 
1991; Kim et al., 1995). Due to its antioxidant action, this enzyme functions in sperm protection (Kim et al., 1995), consistent with the present results, whereas in the present study there was a greater abundance of ribonuclease in the seimal plasma of males of the group classified to have greater sperm motility.

The 14-3-3 protein zeta/delta is an acidic protein found in the epididymal fluid (Kelly et al., 2006) and testis of bulls (Chapin et al., 2001; Wong et al., 2008). These molecules function as binding proteins, which participate in the synthesis, interactions and cellular transport of proteins (Jin et al., 2004; Shikano et al., 2006), mediating the interaction of macromolecules with the sperm cell, being of fundamental importance for spermatogenesis (Wong et al., 2008; Sun et al., 2009). This protein also facilitates spermiation (Sun et al., 2009), and regulates the restructuring that occurs during spermatogenesis (Wong et al., 2008). Furthermore, this protein is involved in maturation and development of sperm motility in the epididymis of bulls and is also associated with fertility (Huang et al., 2015). The 14-3-3 protein zeta/delta modulates action of protein phosphatase 1 (PP1 $\gamma$ ) in tail of spermatozoa, which when in greater concentrations inhibits sperm motility (Huang et al., 2002), inhibiting its catalytic activity, thereby preventing losses in sperm motility (Huang and Vijayaraghavan, 2004). The results of the present study are consistent with these functions of PP1 $\gamma$ because greater amounts of this protein were detected in the seminal plasma of males that were classified to have greater sperm motility.

Acrosin inhibitor is a glycoprotein found in the tail of the epididymis, prostate, bulbourethral glands, and seminal vesicles of bulls, buffalo and boars (Čechová and Fritz, 1976; Tschesche et al., 1976; Čechová et al., 1979; Torska and Strzezek, 1985), which binds to spermatozoa during maturation and ejaculation (Schill et al., 1975; Jonáková and Cechova, 1985; Davidová et al., 2009). In the present study, this protein was in greater concentrations of males that were classified to have greater sperm motility. Acrosin is considered a protease inhibitor and functions to inhibit the activity of sperm proteinases and, thus, preserves sperm integrity (Uhrin et al., 2000). Moreover, the binding of acrosin inhibitor to its receptor on the sperm membrane is modulated, particularly by spermadhesins, which is considered an acceptor molecule and protects the spermatozoa from acrosin actions until fertilization has occurred (Jonáková et al., 1992; Jelínková et al., 2003; Davidová et al., 2009). Acrosin is an enzyme that functions as an acrosomal protease, being of fundamental importance at the time of fertilization, participating in the lysis of the zona pellucida and subsequent penetration of the spermatozoa into the oocyte (Adham et al., 1997; Gurupriya et al., 2014). Thus, the acrosin inhibitor binds to the acrosin present in seminal plasma that contributes to sperm deathand in doing so inhibits the proteolytic effect from occurring prematurely during transit of sperm cells in the male reproductive tract (Sanz et al., 1992; Jonáková, 1994).

Prosaposin is a lysosomal protein found in Sertoli cells and the lumen of the seminiferous tubules and epididymis of mammals (Leonova et al., 1996; Amann et al., 1999a, 1999b). This protein contributes to the sperm-oocyte binding, fertilization and embryo development in several species, including cattle, when added to in vitro culture media (Hammerstedt et al., 1997; Amann et al., 1999a). Increases in amounts of prosaposin is associated with increased pregnancy rates when added to bull semen (Amann et al., 1999b), but its actions have not been elucidated (Ham, 2004). Interestingly, in the present study, the concentrations of prosaposin were correlated with reduced sperm motility, which could be another action of this protein.

Peptide YY has homology with the seminal plasma protein (San Agustin and Lardys, 1990; Herzog et al., 1995) and has been detected in the seminal plasma of bulls being produced by the accessory sex glands (Reddy and Bhargava, 1979; Shivaji, 1984). In the present study, the VIP score to peptide YY was close to 1.0 and was greater in bulls that were classified to have little sperm motility. The peptide has antimicrobial activity in bull seminal plasma (Reddy and Bhargava, 1979; Milos et al., 1988). Peptide YY modulates the structure of calmodulin to inhibit the calcium influx into sperm cells (Rufo et al., 1982) and is considered an antifertility factor that inhibits sperm motility and the acrosome reaction, an event in which involves calcium induced activation (Shivaji and Bhargava, 1987).

In conclusion, the primary functions of proteins found in the seminal plasma of buffalo were catalytic and binding activity. The spermadhesin protein, ribonuclease, 14-3-3 protein zeta/delta, acrosin inhibitor, prosaposin and peptide YY were associated with sperm motility and are potential markers of semen quality.

\section{Authors' contributions}

Substantial contributions to conception and design (V.M.C, F.F.S and E.O); acquisition of data (V.M.C., P.H.Y., R.A.S., F.R.R., P.F.L., C.S., S.B. and E.O.); analysis and interpretation of data (V.M.C, P.H.Y., F.F.S., R.A.S., C.P.F.D. and E.O.); statistical analyses (C.P.F.D, F.F.S and V.M.C.), drafting the manuscript (V.M.C., F.F.S., C.S., R.A.S. and E.O.); critically revising the manuscript for important intellectual content (V.M.C, F.F.S. and E.O.); and final approval of the manuscript for publication (all authors).

\section{Conflicts of interest}

The authors state that they have no conflicts of interest to declare.

\section{Acknowledgments}

The authors would like to thank the Mass Spectrometry at Brazilian Biosciences National Laboratory (LNBio), CNPEM, Campinas, Brazil for support with the NanoAcquity Ultra Performance LC coupled with nanoelectrospray source on Q-TOF Premier mass spectrometer.

This research was financially supported through grants from the São Paulo Research Foundation (Grant 2016/00603-5). 


\section{Appendix A. Supplementary data}

Supplementary material related to this article can be found, in the online version, at doi:https://doi.org/10.1016/j.anireprosci. 2018.06.002.

\section{References}

Adham, I., Nayernia, K., Enzel, W., 1997. Spermatozoa lacking acrosin protein show delayed fertilization. Mol. Reprod. Dev. 46, 370-376.

Akhter, S., Sajjad, M., Andrabi, S.M., Ullah, N., Qayyum, M., 2007. Effect of antibiotics in extender on fertility of liquid buffalo bull semen. Pak. Vet. J. 27, 13-16. Alvarez, J.G., Storey, B.T., 1995. Differential incorporation of fatty acids into and peroxidative loss of fatty acids from phospholipids of human spermatozoa. Mol. Reprod. Dev. 42, 334-346.

Amann, R.P., Hammerstedt, R.H., Shabanowitz, R.B., 1999a. Exposure of human, boar, or bull sperm to a synthetic peptide increases binding to an egg-membrane substrate. J. Androl. 20, 34-41.

Amann, R.P., Seidel, G.E., Brink, Z., 1999b. Exposure of thawed frozen bull sperm to a synthetic peptide before artificial insemination increases fertility. J. Androl. 20, $42-46$.

Andrabi, S.M.H., 2009. Factors affecting the quality of cryopreserved buffalo (Bubalus bubalis) bull spermatozoa. Reprod. Domest. Anim. 44, 552-569.

Anzar, M., Farooq, U., Mirza, M.A., Shahab, M., Ahmad, N., 2003. Factors affecting the efficiency of artificial insemination in cattle and buffalo in Punjab. Pak. Pak. Vet. J. 23, 106-113.

Arangasamy, A., Singh, L.P., Ahmedb, N., Ansari, M.R., Ram, G.C., 2005. Isolation and characterization of heparin and gelatin binding buffalo seminal plasma proteins and their effect on cauda epididymal spermatozoa. Anim. Reprod. Sci. 90, 243-254.

Boutet, E., Lieberherr, D., Tognolli, M., Schneider, M., Bansal, P., Bridge, A.J., Poux, S., Bougueleret, L., Xenarios, I., 2016. UniProtKB/Swiss-Prot, the manually annotated section of the UniProt KnowledgeBase: how to use the entry view. Methods Mol. Biol. $23-54$.

Calvete, J.J., Raida, M., Gentzel, M., Urbankec, C., Sanza, L., Töpfer-Petersen, E., 1997. Isolation and characterization of heparin- and phosphorylcholine-binding proteins of boar and stallion seminal plasma. Primary structure of porcine pBl. FEBS Lett. 407, 201-206.

Čechová, D., Fritz, H., 1976. Characterization of the proteinase inhibitors from bull seminal plasma and spermatozoa. Hoppe Seylers Z. Physiol. Chem. 357, 401-408.

Čechová, D., Jonáková, V., Sedláková, E., Mach, O., 1979. Isolation of basic acrosin inhibitor from bull seminal plasma (BUS! II). Hoppe Seylers Z. Physiol. Chem. 560, 1753-1758.

Chapin, R.E., Wine, R.N., Harris, M.W., Borchers, C.H., Haseman, J.K., 2001. Structure and control of a cell-cell adhesion complex associated with spermiation in rat seminiferous epithelium. J. Androl. 22, 1030-1052.

Checa, A., Bedia, C., Jaumot, J., 2015. Lipidomic data analysis: tutorial, practical guidelines and applications. Anal. Chim. Acta 885, 1-16.

D’Alessio, G., Floridri, A., De Prisco, R., Pignero, A., Leone, E., 1972. Bull semen ribonucleases (purification and physico-chemical properties of the major component). Eur. J. Biochem. 26, 153-161.

D’Alessio, G., Di Donato, A., Parente, A., Picolli, R., 1991. Seminal RNase: a unique member of the ribonuclease superfamily. Trends Biochem. Sci. 16, 104-106.

Daskalova, D., Kukov, A., Kirilova, I., Ivanova-Kicheva, M., 2014. Protein analysis of boar seminal plasma proteins with protective effect during low-temperature storage of spermatozoa. Biotechnol. Biotechnol. Equip. 28, 716-720.

Davidová, N., Jonáková, V., Manásková-Postlerová, P., 2009. Expression and localization of acrosin inhibitor in boar reproductive tract. Cell Tissue Res. 338, 303-311.

Dixit, S., Pandey, V., Swain, D.K., Nigam, R., Sharma, A., Sharma, D., Saxena, A., Sinh, P., 2016. Seminal plasma and sperm membrane proteins of buffalo and cattle bulls: a comparative study. Buffalo Bull. 35, 437-443.

Dostàlovà, Z., Calvete, J.J., Sanz, L., Hettel, C., Riedel, D., Schöneck, C., Einspanier, R., Töpfer-Petersen, E., 1994. Immunolocalization and quantitation of acidic seminal fluid protein (aSFP) in ejaculated, swim-up, and capacitated bull spermatozoa. Biol. Chem. Hoppe Seyler 375, 457-461.

Einspanier, R., Einspanier, A., Wempe, F., Scheit, K.H., 1991. Characterization of a new bioactive protein from bovine seminal fluid. Biochem. Biophys. Res. Commun. 179, 1006-1010.

Erikson, D.W., Way, A.L., Chapman, D.A., Killian, G.J., 2007. Detection of osteopontin on Holstein bull spermatozoa, in caudaepididymal fluid and testis homogenates, and its potential role in bovine fertilization. Reproduction 133, 909-917.

Govindaraju, A., Dogan, S., Rodriguez-Osorio, N., Grant, K., Kaya, A., Memili, E., 2012. Delivering value from sperm proteomics for fertility. Cell Tissue Res. 349, 783-793.

Gurupriya, V.S., Divyashree, B.C., Roy, C.S., 2014. Cryogenic changes in proteases and antiprotease activities of buffalo (Bubalus bubalis) and cattle (Bos taurus) semen. Theriogenology 81, 396-402.

Ham, D., 2004. Prosaposin precursor protein: functions and medical applications-review. Scr. Med. (Brno) 77, $127-134$.

Hammerstedt, R.H., Cramer, P.G., Barbato, G.E., 1997. A Method and Use of Polypeptide in Sperm-Egg Binding to Enhance or Decrease Fertility. WIPO, pp. 1-42.

Harshan, H.M., Singh, L.P., Arangasamy, A., Ansari, M.R., Kumar, S., 2006. Effect of buffalo seminal plasma heparin binding protein (HBP) on freezability and in vitro fertility of buffalo cauda spermatozoa. Anim. Reprod. Sci. 93, 124-133.

Harshan, H.M., Sankar, H.S., Singh, L.P., Singh, M.K., Sudharani, S., Ansari, M.R., Sing, S.K., Majumdar, A.C., Joshi, P., 2009. Identification of PDC-109-like protein(s) in buffalo seminal plasma. Anim. Reprod. Sci. 115, 306-311.

Herold, F.C., Aurich, J.E., Gerber, D., 2004. Epididymal sperm from the African buffalo (Syncerus caffer) can be frozen successfully with AndroMed and with Triladyl $^{\mathrm{TM}}$ but the addition of bovine seminal plasma is detrimental. Theriogenology 61, 715-724.

Herzog, H., Hort, Y., Schneidert, R., Shine, J., 1995. Seminalplasmin: recent evolution of another member of the neuropeptide Y gene family. Proc. Natl. Acad. Sci. U. S. A. $92,594-598$.

Huang, Z., Vijayaraghavan, S., 2004. Increased phosphorylation of a distinct subcellular pool of protein phosphatase, PP1 $\gamma 2$, during epididymal sperm maturation. Biol. Reprod. 70, 439-447.

Huang, Z., Khatra, B., Bollen, M., Vijayaraghavan, S., 2002. Sperm PP1 $\gamma 2$ is regulated by a homologue of the yeast protein phosphatase binding protein sds22. Biol. Reprod. 67, 1936-1942.

Huang, Y.L., Fu, Q., Yang, L., Guan, J.L., Pan, H., Chen, F.M., Lu, K.L., Zhang, M., 2015. Differences between high and low-motility buffalo sperm identified by comparative proteomics. Reprod. Domest. Anim. 50, 443-451.

Ishihama, Y., Oda, Y., Tabata, T., Sato, T., Nagasu, T., Rappsilber, J., Mann, M., 2005. Exponentially modified protein abundance index (emPAI) for estimation of absolute protein amount in proteomics by the number of sequenced peptides per protein. Mol. Cell Proteom. 4, 1265-1272.

Jelínková, P., Manásková, P., Tichá, M., Jonáková, V., 2003. Proteinase inhibitors in aggregated forms of boar seminal plasma proteins. Int. J. Biol. Macromol. 32, 99-107.

Jin, J., Smith, F.D., Wells, C.D., Fawcett, J.P., Kulkarni, S., Metalnikov, P., O’Dnonnell, P., Taylor, P., Taylor, L., Zougman, A., Woodgett, J.R., Langeberg, L.K., Scott, J.D., Pawson, T., 2004. Proteomic, functional, and domain-based analysis of in vivo 14-3-3 binding proteins involved in cytoskeletal regulation and cellular organization. Curr. Biol. 14, 1436-1450.

Jobim, M.I.M., Oberst, E.R., Salbego, C.G., Souza, D.O., Wald, V.B., Mattos, R.C., 2003. Proteínas de baixo peso molecular do plasma seminal bovino relacionadas com a congelabilidade do sêmen através de eletroforese bidimensional em gel de poliacrilamida. Acta Sci. Vet. 31, 21-30.

Jobim, M.I.M., Oberts, E.R., Salbego, C.G., Souza, D.O., Wald, V.B., Tramontina, F., Mattos, R.C., 2004. Two-dimensional polyacrylamide gel electrophoresis of bovine seminal plasma proteins and their relation with semen freezability. Theriogenology 61, 255-266.

Jonáková, V., 1994. Multifunctional sperm protein in gametic interaction. Reprod. Domest. Anim. 11, 115-118.

Jonáková, V., Cechova, D., 1985. Demonstration of an anionic acrosin inhibitor in spermatozoa epididymal fluid and seminal plasma of the boar. Andrologia 17, 466-471.

Jonáková, V., Calvete, J.J., Mann, K., Schäfer, W., Schmid, E.R., Töpfer-Petersen, E., 1992. The complete primary structure of three isoforms of a boar sperm-associated acrosin inhibitor. FEBS Lett. 297, 147-150.

Kelly, V.C., Kuy, S., Palmer, D.J., Xu, Z., Davis, S.R., Cooper, G.J., 2006. Characterization of bovine seminal plasma by proteomics. Proteomics 6, 5826-5833. 
Killian, G.J., Chapman, D.A., Rogowski, L.A., 1993. Fertility-associated proteins in Holstein bull seminal plasma. Biol. Reprod. 49 , $1202-1207$.

Kim, J.S., Soucek, J., Matousekt, J., Raines, R.T., 1995. Catalytic activity of bovine seminal ribonuclease is essential for its immunosuppressive and other biological activities. Biochem. J. 308, 547-550.

Kulkarni, B.A., Rupal, R.K., Hegde, U.C., 1998. Comparative SDS-polyacrylamide gel electrophoresis of seminal plasma proteins and blood plasma proteins of the Indian buffalo and cattle bulls. Indian J. Anim. Sci. 68, 66-67.

Kumar, C.S., Swamy, M.J., 2016. HSP-1/2, a major horse seminal plasma protein, acts as a chaperone against oxidative stress. Biochem. Biophys. Res. Commun. 473, $1058-1063$.

Kumar, A., Singh, L.P., Harshan, H.M., Majumdar, A.C., 2008. Seminal plasma non-heparin binding proteins (NHBP) reduce the cryoinjury to buffalo cauda epididymal spermatozoa induced by heparin binding proteins (HBP). Anim. Reprod. Sci. 104, 220-226.

Kummar, P., Kumar, D., Singh, I., Yadav, P.S., 2012. Seminal plasma proteome: promising biomarkers for bull fertility. Agric. Res. 1 , $78-86$.

Leonova, T., Qi, X., Bencosme, A., Ponce, E., Sun, Y., Grabowski, G., 1996. Proteolytic processing patterns of prosaposin in insect and mammalian cells. J. Biol. Chem. $271,17312-17320$.

Lyra, W.S., Silva, E.C., Araújo, M.C.U., Fragoso, M.D., Veras, G., 2010. Classificação periódica: um exemplo didático para ensinar análise de componentes principais. Quím. Nova 33, 1594-1597.

Manjunath, P., Thérien, I., 2002. Role of seminal plasma phospholipid-binding proteins in sperm membrane lipid modification that occurs during capacitation. J. Reprod. Immunol. 53, 109-119.

Manjunath, P., Nauc, V., Bergeron, A., Ménard, M., 2002. Major proteins of bovine seminal plasma bind to the low-density lipoprotein fraction of hen's egg yolk. Biol. Reprod. 67, 1250-1258.

Matousek, J., Klaudy, J., 1998. Qualitative and quantitative analyses of seminal ribonuclease in reproductive tract fluids of bulls. Anim. Reprod. Sci. 51, 111-118.

Mi, H., Poudel, S., Muruganujan, A., Casagrande, J.T., Thomas, P.D., 2016. PANTHER version 10: expanded protein families and functions, and analysis tools. Nucleic Acids Res. 44, 336-342.

Milos, M., Schaer, J.J., Comte, M., Cox, J.A., 1988. Microcalorimetric investigation of the interaction of calmodulin with seminalplasmin and myosin light chain kinase. J. Biol. Chem. 263, 9218-9222.

Monaco, E., Gasparrini, B., Boccia, L., DeRosa, A., Attanasio, L., Zicarelli, L., Killian, G.J., 2009. Effect of osteopontin (OPN) on in vitro embryo development in cattle. Theriogenology 71, 450-457.

Moura, A.A., Chapman, D.A., Koc, H., Killian, G.J., 2007. A comprehensive proteomic analysis of the accessory sex gland fluid from mature Holstein bulls. Anim. Reprod. Sci. 98, 169-188.

Quayle, A.J., James, K., 1990. Immunosuppression by seminal plasma and its possible biological significance. Arch. Immunol. Ther. Exp. 38, 87-100.

Reddy, E.S.P., Bhargava, P.M., 1979. Seminalplasmin-an antimicrobial protein from bovine seminal plasma which acts in E. coli by specific inhibition of rRNA synthesis. Nature 279, 725-728.

Rego, J.P., Crisp, J.M., Moura, A.A., Nouwens, A.S., Li, Y., Venus, B., Corbet, N.J., Burns, B.M., Boe-Hansen, G.B., McGowan, M.R., 2014. Seminal plasma proteome of eletroejaculated Bos indicus bulls. Anim. Reprod. Sci. 148, 1-17.

Riffo, M.S., Párraga, M., 1997. Role of phospholipase A2 in mammalian sperm-egg fusion: development of hamster oolemma fusibility by lysophosphatidylcholine. J. Exp. Zool. 279, 81-88.

Roncoletta, M., Morani, E.S., Esper, C.R., Barnabe, V.H., Franceschini, P.H., 2006. Fertility-associated proteins in Nelore bull sperm membranes. Anim. Reprod. Sci. 91, 77-87.

Rufo, G.A., Singh, J.P., Babcock, D.F., Lardy, H.A., 1982. Purification and characterization of a calcium transport inhibitor protein from bovine seminal plasma. J. Biol. Chem. 257, 4627-4632.

San Agustin, J.T., Lardys, H.A., 1990. Bovine seminal plasma constituents modulate the activity of caltrin, the calcium-transport regulating protein of bovine spermatozoa. J. Biol. Chem. 265, 6860-6867.

Sanz, L., Calvete, J.J., Jonáková, V., Töpfer-Petersen, E., 1992. Boar spermadhesins AQN-1 and AWN are sperm-associated acrosin inhibitor acceptor proteins. FEBS Lett. 300, 3-66.

Schill, W.B., Heimburger, N., Schiessler, H., Stolla, R., Fritz, H., 1975. Reversible attachment and localization of the acid-stable seminal plasma acrosin-trypsin inhibitors on boar spermatozoa as revealed by the indirect immunofluorescent staining technique. Hoppe Seylers Z. Physiol. Chem. 356, $1473-1476$.

Schöneck, C.J., Braun, R., Einspanier, R., 1996. Sperm viability is influenced in vitro by the bovine seminal protein aSFP: effects on motility, mitochondrial activity and lipid peroxidation. Theriogenology 45, 633-642.

Shikano, S., Coblitz, B., Wu, M., Li, M., 2006. 14-3-3 proteins: regulation of endoplasmic reticulum localization and surface expression of membrane proteins. Trends Cell Biol. 16, 370-375.

Shivaji, S., 1984. Antimicrobial activity of semen. Trends Biochem. Sci. 9, 104-107.

Shivaji, S., Bhargava, P.M., 1987. Antifertility factors of mammalian seminal fluid. BioEssays 7, 13-17.

Singh, L.P., Harshan, H.M., Ansari, M.R., 2007. Effect of egg yolk and seminal plasma heparin binding protein interaction on the freezability of buffalo cauda epididymal spermatozoa. Anim. Reprod. Sci. 99, 395-400.

Singh, M., Ghosh, S.K., Prasad, J.K., Kumar, A., Ramteke, S.S., Bhure, S.K., 2013. Heparin binding proteins of buffalo bulls seminal plasma and their relationship with semen freezability. Indian J. Vet. Anim. Sci. 83, 700-704.

Singh, M., Ghosha, S.K., Prasada, J.K., Kumar, A., Tripathia, R.P., Bhureb, S.K., Srivastava, N., 2014. Seminal PDC-109 protein vis-à-vis cholesterol content and freezability of buffalo spermatozoa. Anim. Reprod. Sci. 144, 22-29.

Singleton, C.L., Killian, G.J., 1983. A study of phospholipase in albumin and its role in inducing the acrosome reaction of guinea pig spermatozoa in vitro. J. Androl. 4, $150-156$.

Souza, C.E., Moura, A.A., Monaco, E., Killian, G.J., 2008. Binding patterns of bovine seminal plasma proteins BSP A1/A2, BSP 30 kDa and osteopontin on ejaculated sperm before and after incubation with isthmic and ampullary oviductal fluid. Anim. Reprod. Sci. 105, 72-89.

Souza, C.E.A., Moura, A.A., Lima-Souza, A.C., Killian, G.J., 2011. Binding patterns of seminal plasma plasma proteins on bovine epididymal and ejaculated sperm membrane. Arq. Bras. Med. Vet. Zootec. 63, 535-543.

Sun, S., Wong, E.W.P., Li, M.W.M., Lee, W.M., Cheng, Y., 2009. 14-3-3 and its binding partners are regulators of protein-protein interactions during spermatogenesis. J. Endocrinol. 202, 327-336.

Thérien, I., Soubeyrand, S., Manjunath, P., 1997. Major proteins of bovine seminal plasma modulate sperm capacitation by high-density lipoprotein. Biol. Reprod. 57, 1080-1088.

Thérien, I., Moreau, R., Manjunath, P., 1998. Major proteins of bovine seminal plasma and high-density lipoprotein induce cholesterol efflux from epididymal sperm. Biol. Reprod. 59, 768-776.

Thérien, I., Moreau, R., Manjunath, P., 1999. Bovine seminal plasma phospholipid-binding proteins stimulate phospholipid efflux from epididymal sperm. Biol, Reprod. 61, 590-598.

Torska, J., Strzezek, J., 1985. Activity of acrosin inhibitors in bull seminal plasma in an annual cycle. Comp. Biochem. Physiol. 81, 519-522.

Tschesche, H., Kupfer, S., Klauser, R., Fink, E., Fritz, H., 1976. Structure, biochemistry and comparative aspects of mammalian seminal plasma acrosin inhibitors. Protides Biol. Fluids 23RD Colloquium 23, 255-266.

Uhrin, P., Dewerchin, M., Hilpert, M., Chrenek, P., Schöfer, C., Zechmeister-Machhart, M., Krönke, G., Vales, A., Carmeliet, P., Binder, B.R., Geiger, M., 2000. Disruption of the protein C inhibitor gene results in impaired spermatogenesis and male infertility. J. Clin. Invest. 106, 1531-1539.

Villén, J., Gygi, S.P., 2008. The SCX/IMAC enrichment approach for global phosphorylation analysis by mass spectrometry. Nature $10,1630-1638$.

Wempe, F., Einspanier, R., Scheit, K.H., 1992. Characterization by cDNA cloning of the mRNA of a new growth factor from bovine seminal plasma: acidic seminal fluid protein. Biochem. Biophys. Res. Commun. 183, 232-237.

Wong, E.W.P., Mruk, D.D., Lee, W.M., Cheng, C.Y., 2008. Par3/Par6 polarity complex coordinates apical ectoplasmic specialization and blood-testis barrier restructuring during spermatogenesis. PNAS 105, 9657-9662.

Xia, J., Wishart, D.S., 2016. Using MetaboAnalyst 3.0 for comprehensive metabolomics data analysis. Curr. Protoc. Bioinform. 55, 1-91. 